ROBERT MUHA, Ph.D.

E-mail: Robert.Muha@fpp.uni-lj.si

University of Ljubljana,

Faculty of Maritime Studies and Transportation

Pot pomorščakov 4, SI-6320 Portorož, Republic of Slovenia

DRAGO SEVER, Ph.D.

E-mail: Drago.Sever@uni-mb.si

University of Maribor, Faculty of Civil Engineering

Smetanova 17, SI-2000 Maribor, Republic of Slovenia
Transport Law

Review

Accepted: June 30, 2008

Approved: Dec. 22, 2008

\title{
THE IMPACT OF REGULATION 561/2006 ON FLEET MANAGEMENT VIEWED THROUGH EFFICIENT USE OF DRIVERS' WORKING TIME
}

\begin{abstract}
The introduction of contemporary procedures to fleet management processes has recently changed the work planning and supervision of driver's work activities. Tendencies to control the implementation of driver's work have been present in modern professional practice for quite a long time; however, the equipment available on the market limited its implementation. The intensified development of digital tachographs has, in technical terms, ensured such equipment considerably before the legislative groundwork was prepared for its practical implementation. The Commission Regulation (EC) No. 561/2006 (implementation of Social legislation relating to Road Transport) does not bring any essential novelties in terms of permitted workload. Consistent monitoring of drivers activities, made possible by digital tachographs, will have impact on the existing working methods. The topic of the present paper is in deep analysis of the impact of the mentioned regulation with special emphasis on the conditions for the regulation of the current stage of drivers work and on the expected consequences. The essential importance lies on the expected change in the mentality and approach to planning the driver's activities in the transport process on the part of the carrier: the outcome will eventually result in the efficiency of each individual carrier.
\end{abstract}

\section{KEY WORDS}

fleet management, driver's work planning, digital tachographs

\section{INTRODUCTION}

It is taken for granted that the safety in road transport depends on three underlying elements - driver, vehicle, and environment - standing for the conditions on the road. These factors are interrelated and form the groundwork for achieving better safety. The comprehensiveness and integrity of all elements, and primarily their concurrence is the prerequisite for improving the level of road safety. In fact, this is the goal of the participants in road safety as well as the wider community.

The responsibility for maintaining the optimal condition of traffic infrastructure rests on the managing authority (the State or Municipalities). For vehicles, the technical requirements are defined by regulations that apply to type-approval (homologation), roadworthiness tests or preventive check-ups, and other technical standards regulating this area. In the concern for the professional driver - the most relevant factor for road safety, there is a number of various influences and interests that directly affect the method and quantity of work of professional drivers involved in road transport. There is an interplay of requirements in respect of the organization of working time in order to assure the required psychophysical profile of the driver on the one hand, and the tendency (or rather necessity) for achieving the highest possible employment (utilization) of the fleet on the other hand - thereby increasing the drivers' workload - as an aftermath of competition in the transportation market. It is therefore necessary to balance these wide-ranging interests in view of protecting the health of drivers, which is so closely interrelated with safety on the road.

According to the Census of population, households and housings in 2002, the number of registered drivers, operators of transport mechanisation and machines (Slovenian nationals) was $34,251^{1}$. During the ten-year term between 1998 and 2007, the number of commercial vehicles increased by $4 \%$ on average in the Republic of Slovenia (Figure 1) and reached 71,221 vehicles in 2007. Assuming that on the average, each registered vehicle needs at least one driver, it is estimated that more than 70,000 drivers of commercial vehicles should be acting (registered), which additionally supports these problematic issues. 


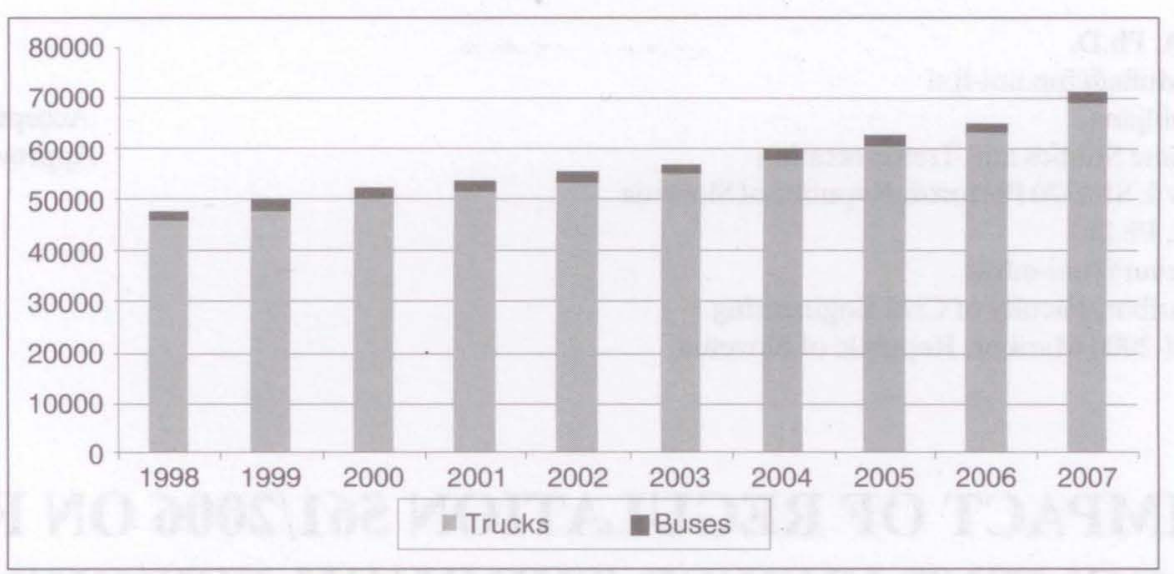

Figure 1- Number of commercial vehicles in the Republic of Slovenia from 1998 to 2007

Source: Statistical Office of the Republic of Slovenia (SURS)

Unlike most professions, the nature of work of professional drivers in road transport does not enable a regular (evenly spread) scheduling and an even distribution of working hours during their work (performing the services). Numerous elements affect the fragmentation of the working day of a driver, which the organizer of road transport has to bear in mind, in particular:

- customer's (the ordering party) demand for punctuality regarding the collection of goods,

- consignee's demand for punctuality of delivery of goods/consignment,

- weather situation,

- unforeseeable traffic hold-ups and congestions on roads,

- activities required at the collection/ delivery point,

- arranging other administrative issues (procedures at border crossing and similar).

\subsection{Subject of research, research purposes and goals, scientific hypothesis}

European Union regulations (orders and directives) represent the common legal frame for the arrangement of the current state in different areas. Its purpose is to establish the unique origins for non-discriminate and comparable regulation of defined area in all member states. In accordance with the established principles, the European legislation is transformed into national legislation, where based on local circumstances the essential measure is ordered. Traffic safety assurance is one of the most important areas of national legislation. After legislation is accepted, the application of legal measures must be made. To avoid unexpected problems due to legislation application in real environment some additional researches regarding local characteristics have to be made. The subject of the presented research is to define the sense and impacts of European Commission regulation (EC
No. 561/2006) on Slovenian national transportation economy.

The research purposes are to recognize the sense and impact of the Commission order on the exploitation method of the drivers working time, to investigate the possible ways to adapt the planning drivers working time process (fleet management) and to contribute to development the transportation economy. The research goal is to make the mentioned transition easier and simpler and to guarantee that demands and expectations of all the social partners could be taken into consideration.

The key research guidance is the scientific hypothesis which runs as follows: "Carrying the demands of European Commission regulation (EC No. 561/2006) into effect has a significant importance for traffic safety and to guarantee the relevant (social) safety of the key subject of road transportation economy".

In the frame of the mentioned scientific hypothesis, the following questions are taken into consideration:

- Why is the limitation of drivers working time important?

- What are the key conditions for regulating the driver social status?

- Which impacts could be expected on the area of drivers working time planning? and

- How to control the realisation of positive legislation demands?

\section{WHY RESTRICTIONS IN DRIVERS' WORKING TIME?}

The interest of employers is based on the economy - employment of their vehicles and technical means to the greatest extent possible, which means as long working hours as possible. The use of a vehicle/ means of transport directly depends on its operator, i. e. an individual driver. In the production industries, work 


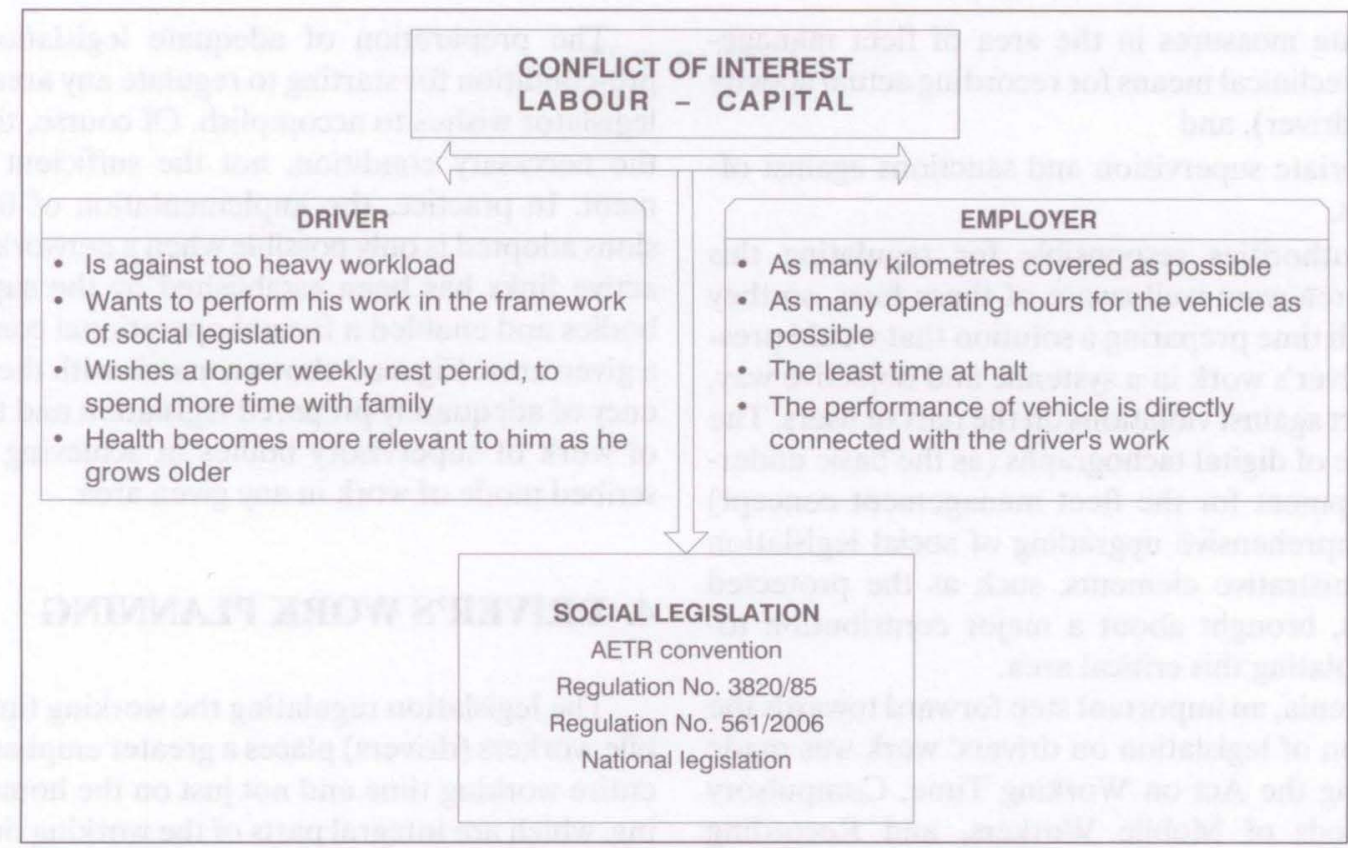

Figure 2 - Conflict of interest between Employers and Drivers

Source: Author

time is scheduled and limited to shifts, a definite number of working hours per week or month. On the other hand, the characteristics of the services involved in road transport, as mentioned above, cannot bear any restrictions of that kind and hence cannot be applied to drivers. The driver's work is not only driving the journey, but involves many other indispensable activities that take place during the work time of the individual worker and that are necessary for the execution of the transport by road. It concerns the idle time a professional driver spends during individual manipulations or the time used in arranging obligatory administrative formalities with the Customs Administration, which are part of the work time of each individual.

Moreover, it should be noted that driving - operating the vehicle in road traffic - demands complex psycho-physical activities, as well as the requirement for 'active period' compliance, i. e. sufficient rest times for physical regeneration and thereby the readiness of the driver for safe operation of the vehicle after resting.

As the professional driver's work cannot be determined in advance and converted into standard work schedule, regulations were prepared that regulated this segment in a rather flexible way that was acceptable to both, the employer and the driver. The interest of the former for the longest exploitation time of vehicle possible was met by a counterbalance that followed the interest protecting the drivers' health and establishing suitable work environment for them. Sufficient, but first and foremost correctly scheduled rest in terms of time, are the underlying facts for good health condition of drivers during their work.
Certain "Regulations or Rules" were adopted long ago (the Convention Regulating the Working and Rest Times for Drivers (AETR), the Regulation No. $3820 / 85^{2}$, the Regulation $3821 / 85^{3}$ and other) regulating the permitted number of driving hours and mandatory rest periods for professional drivers and mandatory equipment for commercial vehicles. These restrictions aimed at achieving the required psychophysical readiness of the driver, which has an immediate influence on his rational acting and handling at the wheel and thereby contributing to a better safety on the road. The purpose of such regulations was to protect the driver's health over his entire service life. We need to be aware that driving is a complex and demanding activity; the nature of work, physical and psychical load on the driver often results in disability from work. Workload above the permitted extent, lasting over many years, can only add to the harmful effect on the health of an individual driver, and raise the probability of detrimental health defects. The disabled fall to the burden of the whole society, not only the respective legal entities from which the disability from work may result.

\section{REGULATION REQUIREMENTS REGARDING SCOPE OF WORK AND STATUS OF DRIVERS}

Some underlying prerequisites for achieving adequate work conditions for drivers and supporting personnel need to be satisfied:

- preparation of regulations (social protection and labour legislation); 
- adequate measures in the area of fleet management (technical means for recording actual activity of the driver), and

- appropriate supervision and sanctions against offenders.

The authorities responsible for regulating this complex area were well aware of these facts, so they spent much time preparing a solution that would present the driver's work in a systemic and objective way, and protect against violations on the part of users. The occurrence of digital tachographs (as the basic underlying equipment for the fleet management concept) and a comprehensive upgrading of social legislation and administrative elements, such as the protected user cards, brought about a major contribution towards regulating this critical area.

In Slovenia, an important step forward towards the preparation of legislation on drivers' work was made by adopting the Act on Working Time, Compulsory Rest Periods of Mobile Workers, and Recording Equipment (Tachographs) in Road Transport (ZDCOPMD), published in the Official Gazette of the Republic of Slovenia /Ur. l. RS/ no. 76/05. The Act was harmonised with a number of Directives of the European Parliament and the Council that systematically regulate this fairly complex area of mobile workers. To date, this Act (ZDCOPMD) has undergone some changes and the official consolidated text was published in the Official Gazette Ur. 1. RS, No. $64 / 2007$. However, it is not the purpose of this Paper to present the provisions of the law in full detail, so the focus will be restricted to the most relevant provisions of the Regulation No. 561/06 ${ }^{4}$, that introduced digital tachographs and brought some novelties that will have a bearing on the planning and supervision of drivers' work.

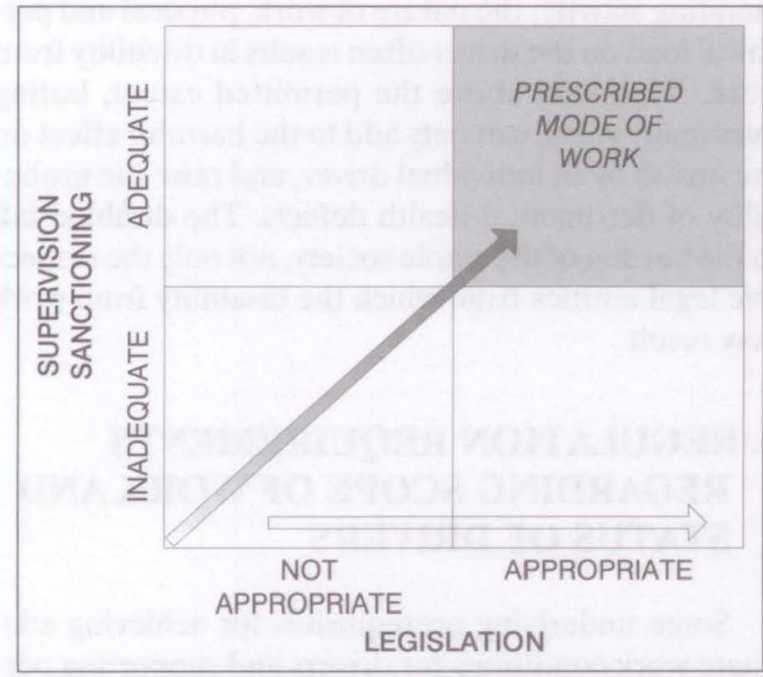

Figure 3 - Achieving the prescribed mode of work in a given area
The preparation of adequate legislation is the pre-condition for starting to regulate any area that the legislator wishes to accomplish. Of course, this is just the necessary condition, not the sufficient requirement. In practice, the implementation of the provisions adopted is only possible when a network of interactive links has been established by the supervisory bodies and enabled a factual operational condition in a given area. Figure 3 shows a matrix with the dependency of adequately prepared legislation and the mode of work of supervisory bodies in achieving the prescribed mode of work in any given area.

\section{DRIVER'S WORK PLANNING}

The legislation regulating the working time of mobile workers (drivers) places a greater emphasis on the entire working time and not just on the hours of driving, which are integral parts of the working time. It actually prescribes that the driver's work be evaluated according to the hours invested in work process and not just based on the hours of actual driving. Numerous disagreements between Employers and Representatives of drivers were known in the past and emerged on different evaluation of the hours of work performed.

Regulation 561/06 places more emphasis on the length of the weekly rest periods of drivers, as well as on the actual utilization of reduced (shorter) weekly rest periods. Highlighted are periods of longer one-off rest period in which a driver can better regenerate for further work. It is known that a reduced daily rest period is no longer being compensated under the new regulation. Instead, it is prescribed that the driver must use his entire weekly rest period ( 45 hours) every second week, and in between he can use the reduced weekly rest period between 24 and 45 hours.

These changes certainly have an impact on the practices applied in drivers' work planning and also on the planning of availability of the vehicle. Particular attention should be dedicated to the planning of longer rest periods of the driver that are directly linked to the permitted hours of driving in any two weeks - limited to 90 hours. Owing to a cyclic occurrence of the weekly rest period there are, in principle, two options:

- balancing the number of driving hours during each week to ca. $40-50$ hours and acting in line with the demand not to reduce the shortened weekly rest period in between too much - aiming to avoid too frequent requests for compensation of unused hours of weekly rest (Figure 4);

- using the maximum number of hours of driving in one week, and then using the remaining time of the shortened weekly rest period during the other week with less driving hours scheduled - see Figure 5. 


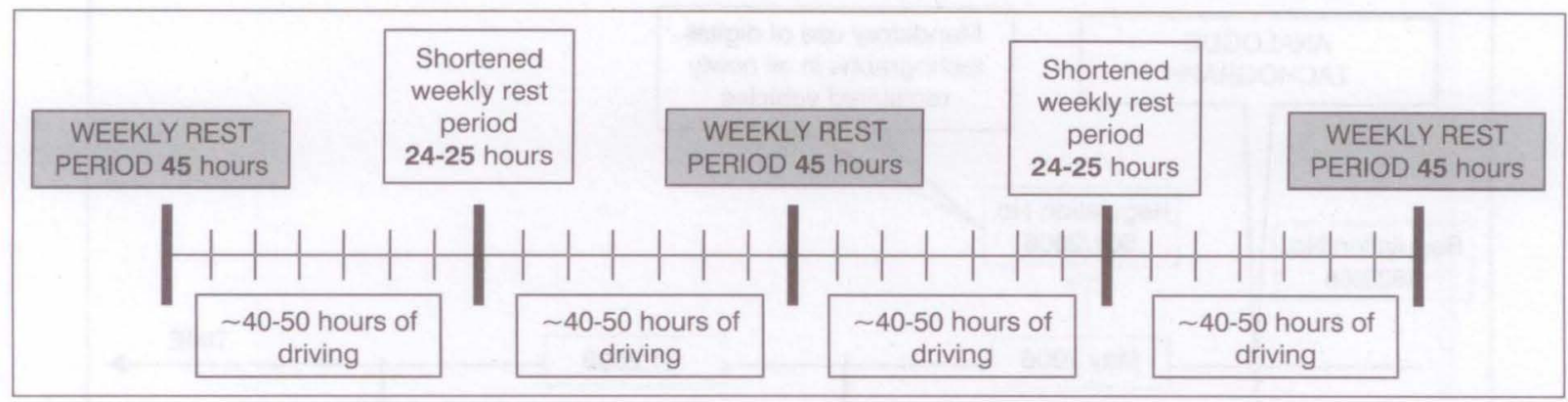

Figure 4 - Balancing the number of driving hours over several weeks

Source: Author

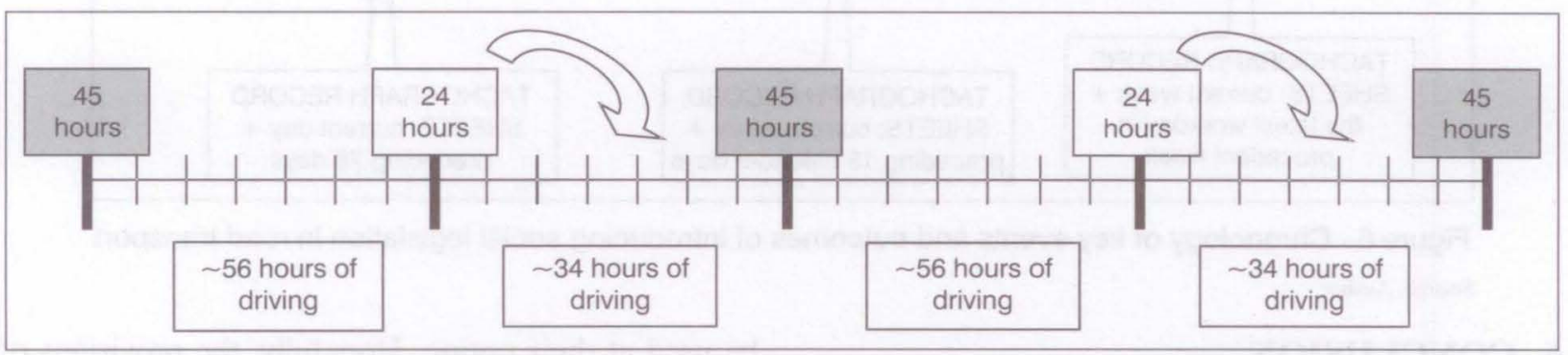

Figure 5 - Carry-forward of unused hours of weekly rest on a current basis

Source: Author

The rule that the unused hours of weekly rest period need to be used with any 9-hour rest period within the time limit of three weeks aggravates the planning of driver's availability. If that happens regularly and insufficient attention is paid to that issue, it may often occur that the time limit for compensation will expire. Therefore, I find the first option slightly more appropriate, when the availability is planned on each fully used weekly rest period of a driver.

These are only two roughly framed options: each carrier will seek the most suitable mode of planning for itself, depending on the demand. Compliance with the carry-forward and actual utilisation of unused weekly rest periods on a current basis will become a fairly demanding task for each carrier. Planning of driver's work will become one of the more relevant elements in the planning of a transport service in terms of time and costs. It can be expected that some indicators of physical utilisation of the fleet (truck-accounting day) will deteriorate. As a result, the costs of transport services will rise and that can only be achieved by joint effort and unified approach of all road carriers appealing to their customers towards a compromise, understanding their position in the newly created operating environment.

\section{SUPERVISING THE IMPLEMENTA- TION OF THE SOCIAL LEGISLATION}

The most relevant change in supervising the implementation of social legislation in the segment of road transport was the adoption of the Regulation 561/2005 that replaced the Regulation No. $3821 / 85$ and imposed compulsory use of the digital tachograph for all new-registered commercial vehicles after 1 May 2006.

In addition, it introduced the novelty for drivers of commercial vehicles who still use analogue tachographs: with effect from 1 January 2008 they need to carry in their cockpit the number of obligatory record sheets for the tachograph covering the same period of time as the activities of the driver are recorded on the driver's card in a digital tachograph. The chronology of key events and outcomes of introducing social legislation in road transport is shown in Figure 6.

The Regulation was adopted due to the fact that the effectiveness of the control over professional drivers in road traffic and taking the required measures on the offenders are not at a satisfactory level. The latter generally applies to the entire European segment of road transport. Therefore, introducing the digital tachographs aimed at restricting the malpractices in driving hours and rest periods in view of protecting the health of professional drivers and thereby to raise the level of safety in road traffic.

The digital tachograph is not only a mere piece of basic technical equipment that allows the organizer of road transports to control the driver and improve the efficiency of its fleet management, but rather the key equipment to provide social security to professional drivers whose scope of work has to be restricted to an acceptable level in order to assure traffic safety. The latter is determined by consensus of all social partners in this economic area. 


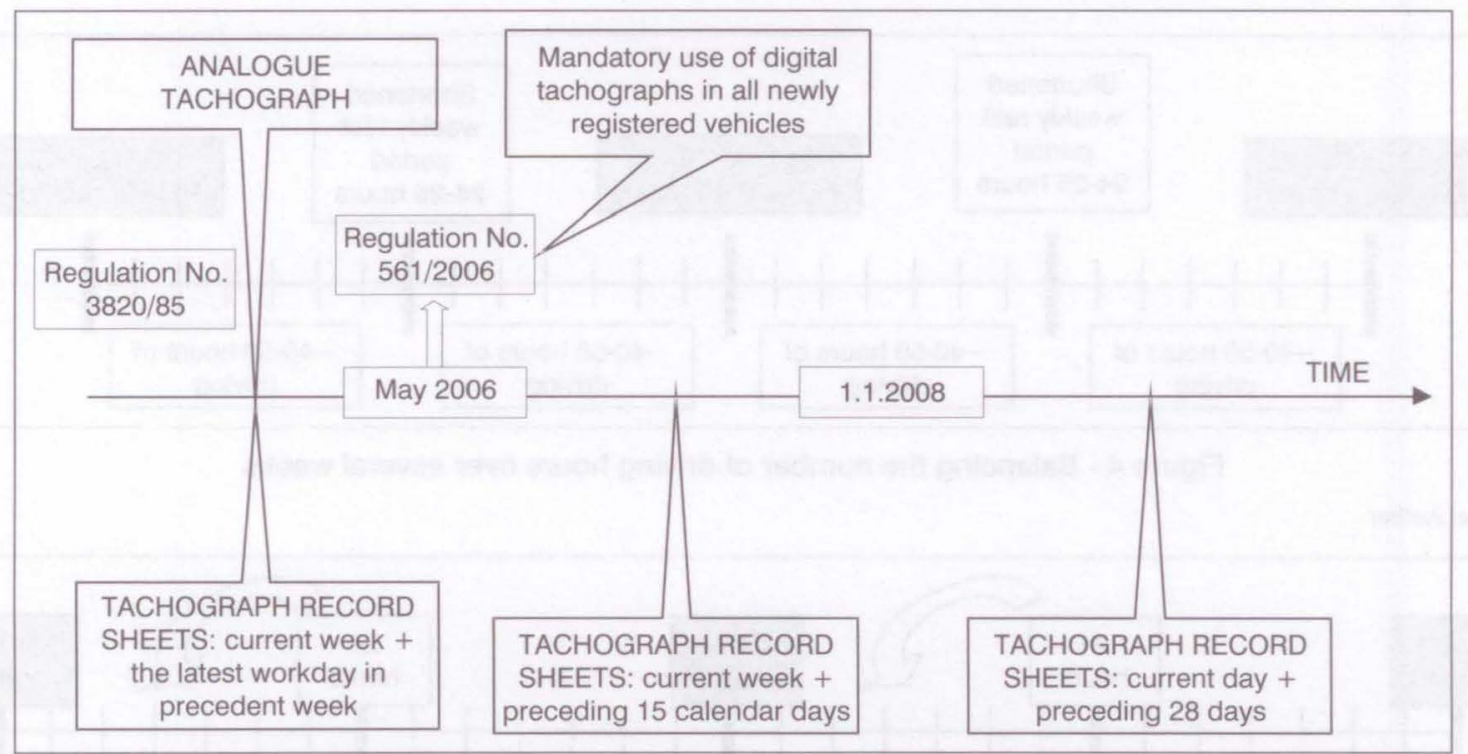

Figure 6 - Chronology of key events and outcomes of introducing social legislation in road transport Source: Author

\section{CONCLUSION}

The introduction of digital tachographs will reflect in several aspects in outcome on multiple levels, affecting the work of both haulers and inspection authorities. Despite the abundance of technical and other changes already introduced in the area of road transport, the digital tachograph represents such a change as no other novelty has brought about to date. In terms of cost, this novelty is not problematic - it only introduces a new device at a negligibly higher cost of purchase compared with the analogue tachograph. Much more relevant is the impact on the work of professional drivers and on the planning of transport process, which reflects on the cost side of the carrier's operation.

Along the introduction of digital tachographs, we need to mention the problematic issue of this deficient profession - a chronic shortage of drivers over several years. In part, this was addressed by employing the drivers from other countries, and partly by imposing a higher workload on the existing employees. That will no longer be practicable in the same scope and manner as it has been to date. The driver's profession has lost some of its attraction, compared with the previous years, on the account of earnings, which are no longer such as to attract young people to become professional drivers. What is more, the time spent on route away from the driver's home and family is an unfavourable side-effect. Accordingly, many potential drivers opt for a less paid work with more free time to be used at their option. Hopefully, the provisions of Regulation No. 561/2006 that place emphasis on longer weekly rest periods may bring some favourable response from potential candidates for this profession. The assurance that the driver will be able to spend several weekends at home may be encouraging and make this profession more attractive.

The introduction of digital tachographs and the stricter supervision over the professional drivers may become an opportunity for the haulers to approach the market jointly, take part in negotiations with their customers and achieve a raise in their freight rates. The latter were formed in the past when work could be done in a "slightly" different way than it is required for the future. First of all, this new approach will have to be accepted by the carriers. Nevertheless, we are moving towards the time when the compliance with Regulation No. 561/2005 will be binding on all carriers and become the general rule for the work of professional drivers. We need to accept this fact. It is only after the carriers have accepted this principle that their customers will be able to follow and adopt it. Of course, such changes cannot happen over night - they need certain time for the implementation of novelty in practice.

The performed research report shows that the systematic approach to regulate the area of national transportation regulation is essential; positive European regulation is the important guidance. The mentioned approach could have important impact on the driver's social safety and on traffic safety consequently. It could be stated that the scientific hypothesis has been proven. 


\section{Dr. ROBERT MUHA}

E-mail: Robert.Muha@fpp.uni-lj.si

Univerza v Ljubljani, Fakulteta za pomorstvo in promet

Pot pomorščakov 4, 6320 Portorož, Republika Slovenija

Dr. DRAGO SEVER

E-mail: Drago.Sever@uni-mb.si

Univerza v Mariboru, Fakulteta za gradbeništvo

Smetanova 17, 2000 Maribor, Republika Slovenija

\section{POVZETEK}

VPLIV UREDBE 561/2006 NA UPRAVLJANJE Z VOZNIM PARKOM S POUDARKOM NA IZKORIŠČENOSTI DELOVNEGA ČASA VÖZIKA

Uvedba sodobnih postopkov v procese upravljanja $z$ voznim parkom je v zadnjem času spremenila način načrtovanja dela voznega osebja ter nadzor nad njegovimi delovnimi aktivnostmi. Težnje po nadzoru izvajanja voznikovega dela so v strokovni praksi prisotne že dalj časa, njena realizacija pa je bila omejena z razpoložljivo opremo na tržišču. Pospešen razvoj digitalnih tahografov je v tehničnem smislu takšno opremo zagotovil bistveno prej, kot so bile urejene zakonodajne podlage za njegovo uvedbo v prakso. Uredba evropske komisije 561/2006 (Socialna zakonodaja v zvezi s cestnim transportom) sicer ne prinaša bistvenih novosti glede dovoljenih obremenitev. Zaradi doslednejše spremljave voznikove aktivnosti, ki jo omogočajo digitalni tahografi, pa bo vplivala na dosedanji način njihovega dela. Predmet pričujočega prispevka je detajIna analiza vpliva uredbe s posebnim poudarkom na pogojih za ureditev stanja na področju dela voznikov ter pričakovanih posledic. Ključnega pomena je pričakovana sprememba načina razmišljanja in dela prevoznikov pri načrtovanju voznikovega dela v transportnem procesu, kar bo vplivalo na uspešnost poslovanja posameznega prevoznika.

\section{KLJUČNE BESEDE}

upravljanje z voznim parkom, planiranje dela voznikov, digitalni tahografi

\section{REFERENCES}

1. Source: Statistical Office of the Republic of Slovenia (SURS)
2. Council Regulation (EEC) No $3820 / 85$ of 20 December 1985. on the harmonisation of certain social legislation relating to road transport

3. Council Regulation (EEC) No $3821 / 85$ of 20 December 1985 on recording equipment in road transport Official Journal L 370

4. Regulation (EC) No 561/2006 of the European Parliament and of the Council of 15 March 2006 on the harmonization of certain social legislation relating to road transport and amending Council Regulations (EEC) No $3821 / 85$ and (EC) No 2135/98 and repealing Council Regulation (EEC) No 3820/85

\section{LITERATURE}

[1] Muha R., Impact of digital tachographs on drivers' mode of work, ICTS, Portorož 2006.

[2] Muha R., Nič bistveno novega, pa vendar tako zelo drugače, Katalog prireditve Transport-Logistika-Dnevi prevoznikov, Ljubljana 2008.

[3] Regulation (EC) No 561/2006 of the European Parliament and of the Council of 15 March 2006 on the harmonisation of certain social legislation relating to road transport

[4] Council Regulation (EEC) No 3820/85 of 20 December 1985 on the harmonisation of certain social legislation relating to road transport

[5] Council Regulation (EEC) No 3821/85 of 20 December 1985 on recording equipment in road transport Official Journal L 370

[6] Act on Working Time, Compulsory Rest Periods of Mobile Workers, and Recording Equipment (Tachographs) in Road Transport (ZDCOPMD), published in the Official Gazette of the Republic of Slovenia /Ur. $l$. RS/ 76/05, 64/07.

\section{Internet Homepages:}

[7] Http://ec.europa.eu/transport/road/policy/ social_provision/social_driving time_en.htm

[8] Http://www.fiabrussels.org/en/news articles/archive/ social_legislation_in_road_transport_digital_ tachographs.htm

[9] Http://www.transportal.si/zakonodaja/ digitalni_tahograf_in_delovni_cas_voznikov/ Page-8.html 